\title{
Short communication: Proteins in heat-processed skim milk powder have no positive effects on bone loss of ovariectomized rats
}

\author{
M. Du, ${ }^{*}$ Y. Kong, ${ }^{\star}$ C. Wang, + H. Gao, ${ }^{*}$ X. Han, ${ }^{\star}$ H. Yi, ${ }^{\star}$ and L. Zhang ${ }^{\star 1}$ \\ *School of Food Science and Engineering, Harbin Institute of Technology, Harbin 150090, China \\ †College of Food Science, Northeast Agricultural University, Harbin 150030, China
}

\begin{abstract}
Milk has positive effects on bone growth. However, the effect of skim milk powder (SMP) on bone properties has not been reported. This study investigated the effect of SMP on bone loss in ovariectomized (OVX) rats. Forty female Sprague-Dawley rats were ovariectomized and another 10 rats received a sham operation. The OVX rats were randomly separated into 4 groups: OVX control, OVX SMP1 (SMP at $0.04 \mathrm{~g} / \mathrm{d}$ ), OVX SMP2 (SMP at $0.20 \mathrm{~g} / \mathrm{d}$ ), and OVX SMP3 (SMP at $0.40 \mathrm{~g} / \mathrm{d}$ ). Skim milk powder was supplied in the rat diet for $12 \mathrm{wk}$, and the rats were gavaged once per day. The effects of SMP on calcium content and bone mineral density of femur were determined by atomic absorption spectrophotometry and dual-energy x-ray absorptiometry, respectively. Compared with the control, SMP at all dose levels tested had no particular effect on weight:length, calcium content, or bone mineral density of femurs. It was demonstrated that SMP (0.04 to $0.40 \mathrm{~g} / \mathrm{d}$ ) had no positive effect on bone loss in OVX rats, probably because the heat treatment used during SMP processing caused a loss of biological activity in the protein.
\end{abstract}

Key words: skim milk powder, heat treatment, bone loss, thermosensitive protein

\section{Short Communication}

Osteoporosis is presently one of the most critical global health disorders among postmenopausal women and is caused mainly by the decline in bone mineral density (BMD; Ginty et al., 2005; Gu et al., 2007). Menopause results in elevated bone turnover, an imbalance between bone formation and bone resorption, and decreased BMD. Bioactive factors may affect bone metabolism directly. In this respect, any factors leading to reduction of the rapid menopausal bone loss can impose the perceived risk of osteoporosis in older women. Many

Received December 27, 2010

Accepted March 7, 2011.

${ }^{1}$ Corresponding author: duming2006@yahoo.com.cn studies suggest that milk basic protein (MBP) suppresses osteoclast-mediated bone resorption, increases $\mathrm{BMD}$, and prevents bone loss caused by ovariectomy (OVX; Toba et al., 2001; Pouliot and Gauthier, 2006). Kruger et al. (2006) investigated the ability of whey acidic protein fractions to protect against bone loss due to ovariectomy in mature female rats. Their results indicated that the acidic protein fractions reduced bone loss due to OVX and maintained bone density above OVX levels. Many kinds of growth factors exist in bovine milk, such as transforming growth factor, IGF-1, and IGF-2. These growth factors are capable of promoting the mitosis of osteoblasts from juvenile cells, inducing the synthesis of collagen and matrix protein by osteoblasts, and consequently promoting the formation of bone matrix, calcifying the bone and increasing BMD.

Pasteurization $\left(61.7-62.8^{\circ} \mathrm{C}\right.$ for $30 \mathrm{~min}$ or $71.6^{\circ} \mathrm{C}$ for $15 \mathrm{~min})$ or ultra-high temperature $\left(135-150^{\circ} \mathrm{C}\right.$ for a few seconds) is used in skim milk powder (SMP) production for sterilization. Spray drying is another common procedure in the production of SMP. In the course of spray drying, milk is heated at the inlet of spray nozzle to a relatively high temperature $\left(130-250^{\circ} \mathrm{C}\right)$. Until now, it has not been clear whether these heat treatments influence the functional activity of milk proteins in preventing bone loss.

Although the functions of SMP have been extensively studied, its effects on bone loss have not been reported. Therefore, the objective of the present work was to investigate the effects of SMP on prevention of bone loss in aged OVX rats.

Skim milk powder was prepared according to the regular processing procedures in industry (Wondersun Dairy Company, Hegang, Heilongjiang, China) as shown in Figure 1. Nutritional components of SMP, such as protein, fat, and lactose, were determined using Fourier transform infrared spectrometry (Antaris II FT-NIR Analyzer, Thermo Nicolet, Thermo Electron Scientific Corp., Madison, WI). Calcium content was determined using atomic absorption spectrophotometry (AAnalyst 100, PerkinElmer, Waltham, MA). Results are shown in Table 1. 
Table 1. Composition of nutritional components in skim milk powder

\begin{tabular}{lc}
\hline Composition $(\%)$ & $\begin{array}{c}\text { Content } \\
(\%)\end{array}$ \\
\hline Water & $3 \pm 0.02$ \\
Fat & $2 \pm 0.02$ \\
Protein & $62.7 \pm 2.3$ \\
Lactose & $18.3 \pm 1.3$ \\
Ash & $12.6 \pm 1.1$ \\
Calcium & $<2.3^{1}$ \\
\hline
\end{tabular}

${ }^{1}$ The value was calculated based on the preparation process of skim milk powder and the average calcium content of bovine milk (120 $\mathrm{mg} / 100 \mathrm{~g})$

Fifty female Sprague-Dawley rats (BW of $195 \pm 15$ g) were supplied by the Experimental Animals Center of Harbin Medical University (Harbin, China). Forty of the rats were ovariectomized and the other 10 rats were subjected to a sham operation. The OVX rats were randomly separated into 4 groups: OVX-control, OVX-0.04 g/d SMP (SMP1), OVX-0.20 g/d SMP (SMP2), and OVX-0.40 g/d SMP (SMP3). The dose was selected based on the Dietary Reference Intakes of milk for a Chinese adult ( $60 \mathrm{~kg}$ of BW), $300 \mathrm{~mL}$ of fresh milk per day (Chinese Nutrition Society, 2008), which is approximately equivalent to $150 \mathrm{mg}$ of milk proteins per $\mathrm{kg}$ of BW per day. Based on the average BW of rats in the present study and the nutritional components of the tested SMP (Table 1), a dose range of SMP of 0.04 to $0.40 \mathrm{~g} / \mathrm{d}$ is approximately equal to an intake range of 125 to $1,250 \mathrm{mg}$ of milk proteins per day per $\mathrm{kg}$ of BW. Guidelines for the care and use of animals were followed, and all procedures were approved by the Ethical Committee of Harbin Medical University. The experiment was conducted according to our previous study (Du et al., 2009).

Body weight and bone weight were measured using an analytical balance (FA1004N, MoreChina, Shanghai, China) and bone length using a vernier caliper (Mitutoyo, Tianjin, China). Bone mineral density was

Table 2. Results (mean $\pm \mathrm{SD}, \mathrm{n}=10)$ of femur weight:length $(\mathrm{g} / \mathrm{cm})$ in ovariectomized rats gavaged with skim milk powder (SMP)

\begin{tabular}{lcc}
\hline Group $^{1}$ & $\begin{array}{c}\text { Left } \\
\text { femur }\end{array}$ & $\begin{array}{c}\text { Right } \\
\text { femur }\end{array}$ \\
\hline Sham & $0.2221 \pm 0.0154^{\mathrm{a}}$ & $0.2185 \pm 0.0155^{\mathrm{a}}$ \\
Control & $0.2196 \pm 0.0140^{\mathrm{a}}$ & $0.2156 \pm 0.0144^{\mathrm{a}}$ \\
SMP1 & $0.2210 \pm 0.0141^{\mathrm{a}}$ & $0.2176 \pm 0.0157^{\mathrm{a}}$ \\
SMP2 & $0.2202 \pm 0.0156^{\mathrm{a}}$ & $0.2208 \pm 0.0135^{\mathrm{a}}$ \\
SMP3 & $0.2203 \pm 0.0128^{\mathrm{a}}$ & $0.2163 \pm 0.0131^{\mathrm{a}}$ \\
\hline
\end{tabular}

${ }^{\mathrm{a} N o}$ statistically significant differences were observed for the values in the same column.

${ }^{1}$ Sham $=$ sham operation; control $=$ ovariectomized $(\mathrm{OVX})$ model control; SMP1 = OVX rats gavaged with SMP of $0.04 \mathrm{~g} / \mathrm{d}$; SMP2 $=$ OVX rats gavaged with SMP of $0.20 \mathrm{~g} / \mathrm{d}$; SMP3 $=$ OVX rats gavaged with SMP of $0.40 \mathrm{~g} / \mathrm{d}$.

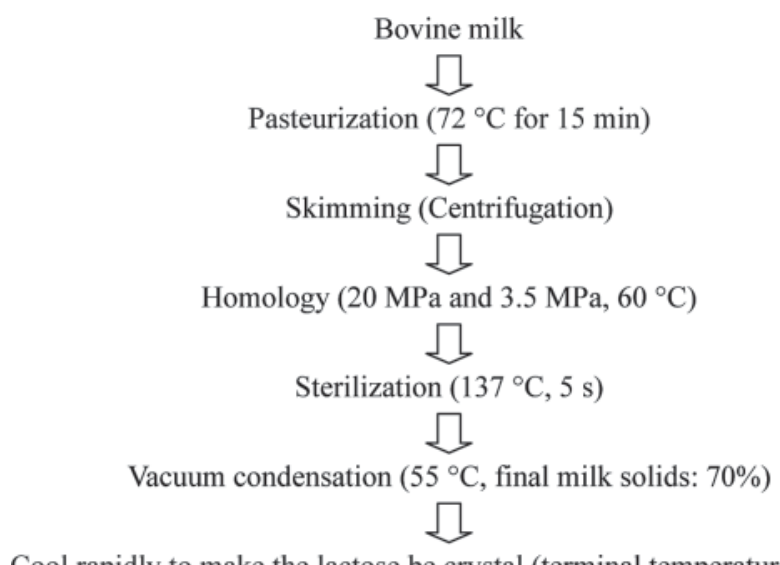

Cool rapidly to make the lactose be crystal (terminal temperature: $10{ }^{\circ} \mathrm{C}$ )

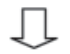

Remove the crystal lactose by centrifugation $(3000 \times g)$

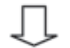

Spray drying (Inlet of spray nozzle temperature: $200^{\circ} \mathrm{C}$ )

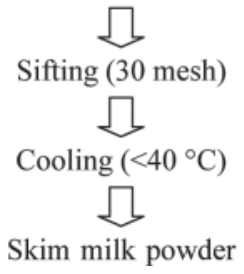

Figure 1. Sample preparation procedure. The primary processing parameters for each step were selected according to the regular processing conditions of skim milk powder (SMP) product in Chinese industrial plants.

measured with dual-energy x-ray absorptiometry, using a Dichroma Scan DCS-600A (Aloka, Tokyo, Japan). Calcium content was determined using atomic absorption spectrophotometry (PerkinElmer AAnalyst 100). Data were statistically analyzed using the SPSS 11.0 software package (SPSS Inc., Chicago, IL) for the ANOVA. Significance was established at $P<0.05$.

The values of weight:length (W:L; left and right) in groups SMP1, SMP2, and SMP3 were not different from those of sham and control groups (Table 2). In addition, the values among groups SMP1, SMP2, and SMP3 were not significantly different, which indicated that SMP had no positive effect on femur weight. Many well-known factors affect $\mathrm{W}: \mathrm{L}$, such as the average area of cross section, the calcium content of marrow, and the density of marrow. Hence, W:L cannot reflect the change of bone density of rats directly, and thus determination of BMD is necessary to assess bone growth.

Results from Figure 2 show that the calcium content in femur did not differ significantly in rats in all tested groups. This suggests that SMP had no beneficial effect on the calcium metabolism of femur in rats and cannot alleviate or suppress the decline in calcium content. 


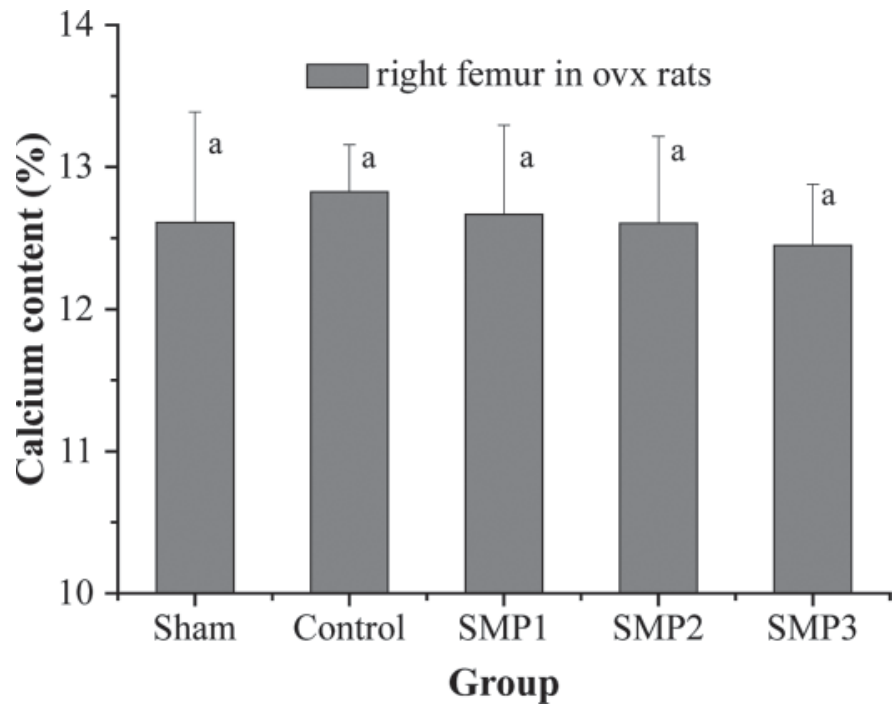

Figure 2. Calcium content of femur in ovariectomized (OVX) rats (mean $\pm \mathrm{SD}, \mathrm{n}=10$ ). The calcium content of each right femur was determined by atomic absorption spectrophotometry. Sham = sham operation; Control $=$ OVX model control; SMP1, SMP2, and SMP3 $=$ OVX rats fed a diet with skim milk powder (SMP) at 0.04, 0.20, and $0.40 \mathrm{~g} / \mathrm{d}$, respectively. ${ }^{\mathrm{a}}$ No statistically significant differences were observed.

The results of BMD determination are shown in Figure 3. The BMD of proximal, middle, and distal end segments in groups SMP1, SMP2, and SMP3 was not different from that of sham and control groups. Moreover, the 3 doses of SMP exhibited stronger activity on BMD at the distal end of the bone, which was also reported by other researchers ( $\mathrm{Lu}$ et al., 2007). This is attributed to the different developing speed of density of the distal end and shaft of femur during the experimental period. Therefore, SMP did not inhibit bone loss due to the declining estrogen in OVX rats.

In the present study, the calcium content in SMP was $<2.3 \%$ (i.e., 2.3 to $23 \mathrm{mg} / \mathrm{d} \mathrm{CaCO}_{3}$ ). However, all animals were fed a diet consisting of $1.25 \%$ calcium (basal dietary composition; i.e., $250 \mathrm{mg} / \mathrm{d}$ of $\mathrm{CaCO}_{3}$ ), which is much higher than the calcium content in SMP. This amount is sufficient to maintain normal bone metabolism, so that the effects of calcium in the SMP samples could be ignored.

Milk can protect against bone loss not only because it contains calcium, but also because it is composed of many functional proteins and growth factors. The beneficial effects of milk and whey proteins on bone loss are attributed to many predominant functional components, including lactoferrin, osteopontin, IGF1, IGF-2, and epidermal growth factor (Pouliot and Gauthier, 2006; Fong et al., 2008). Toba et al. (2001) reported that MBP suppresses bone resorption in a dose-dependent manner ( 0.3 to $3 \mathrm{mg} / \mathrm{d}$ ) because of its

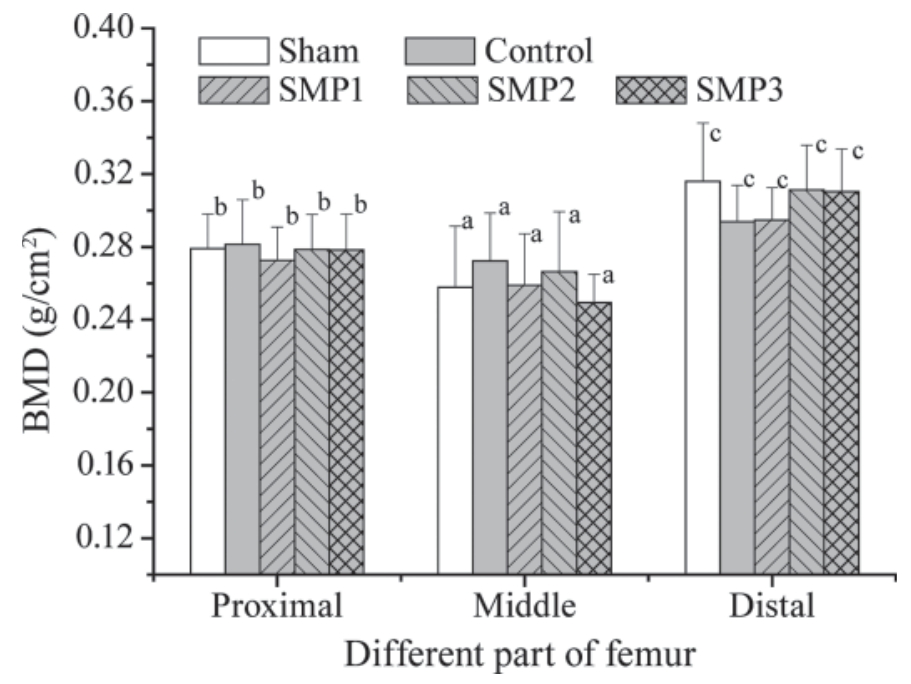

Figure 3. Effect on bone mineral density (BMD) in ovariectomized $(\mathrm{OVX})$ rats (mean $\pm \mathrm{SD}, \mathrm{n}=10)$; BMD was measured by dual-energy $\mathrm{x}$-ray absorptiometry. Proximal $=$ proximal end; Middle $=$ middle segment; Distal $=$ distal end. Sham $=$ sham operation; Control $=$ OVX model control; SMP1, SMP2, and SMP3 = OVX rats fed a diet with skim milk powder (SMP) at 0.04, 0.20, and $0.40 \mathrm{~g} / \mathrm{d}$, respectively. ${ }^{a-c}$ No statistically significant differences were observed for proximal end, middle segment, and distal end, respectively.

direct effect on osteoclasts. A study showed that about $1 \mathrm{mg}$ of $\mathrm{MBP} / \mathrm{kg}$ of $\mathrm{BW}$ was effective in suppressing bone resorption in humans (Zou et al., 2009); $0.8 \mathrm{mg}$ of $\mathrm{MBP} / \mathrm{kg}$ of BW (Uenishi et al., 2007) was shown to be effective in increasing BMD in young women. Lau et al. (2002) reported that $18.8 \mathrm{~g} / \mathrm{d}$ of milk protein prevented bone loss in postmenopausal women. Such a diet for an adult approximates to an intake of $0.2 \mathrm{mg}$ of $\mathrm{MBP} / \mathrm{d}$ or $1.0 \mathrm{mg} / \mathrm{kg}$ of BW for rats.

According to the protein composition of milk (Livney, 2010), 0.04 to $0.40 \mathrm{~g} / \mathrm{d}$ of SMP in the present study approximates to an intake of 0.08 to $0.8 \mathrm{mg}$ of $\mathrm{MBP} / \mathrm{d}$ (Tables 1 and 3) or 0.4 to $4 \mathrm{mg} / \mathrm{kg}$ of BW for rats. Apparently, this dosage includes the effective dosage of MBP in its natural form or in the form of milk protein mentioned above (Uenishi et al., 2007; Zou et al., 2009). Theoretically, the present diet of milk protein must be effective in preventing bone loss of OVX rats if the MBP fraction is active. The negative result in

Table 3. Contents of different proteins in skim milk powder (SMP)

\begin{tabular}{lc}
\hline Protein & $\begin{array}{c}\text { Content } \\
(\mathrm{g} / 100 \mathrm{~g} \text { of SMP })\end{array}$ \\
\hline Total protein & $62.7 \pm 2.3$ \\
Casein & $50.9 \pm 1.5$ \\
Whey protein & $11.8 \pm 0.35$ \\
Milk basic protein & $0.2 \pm 0.01$ \\
\hline
\end{tabular}


the present study indicates that milk protein in SMP is denatured by heat treatment.

Approximately 56\% of MBP is lactoferrin (Goodman et al., 2007), which suggests that lactoferrin is the substance mainly responsible for the beneficial effect of MBP on bone loss of OVX rats (Naot et al., 2005; Grey et al., 2006). However, lactoferrin was found to be unstable against heat treatment under neutral conditions (Brisson et al., 2007). Heat treatment (at $>70^{\circ} \mathrm{C}$ ) caused denaturation and aggregation of lactoferrin through disulfide cross-linking and hydrophobic interactions (Sreedhara et al., 2010). Therefore, loss of biological activity of lactoferrin may result in the loss of beneficial effects of proteins in SMP on bone loss in OVX rat.

In rats, SMP at up to $0.40 \mathrm{~g} / \mathrm{d}$ cannot remediate the bone loss associated with ovariectomy. From a human dietary perspective, $0.40 \mathrm{~g} / \mathrm{d}$ of SMP for a rat (BW of $200 \mathrm{~g}$ ) approximates to an intake of $120 \mathrm{~g}$ of SMP/d for a female $(60 \mathrm{~kg})$. In terms of dietary bone prophylaxis, SMP (12 to $120 \mathrm{~g} / \mathrm{d}$ ) is not significantly beneficial for preventing osteoporosis.

\section{ACKNOWLEDGMENTS}

The project was supported by Natural Scientific Research Innovation Foundation in Harbin Institute of Technology (Harbin, China).

\section{REFERENCES}

Brisson, G., M. Britten, and Y. Pouliot. 2007. Heat-induced aggregation of bovine lactoferrin at neutral $\mathrm{pH}$ : Effect of iron saturation. Int. Dairy J. 17:617-624.

Chinese Nutrition Society. 2008. Dietary Guide for Chinese Residents (2007). Tibetan People Publication, Beijing, China.

Du, M., K. Wang, C. Wu, and L. Zhang. 2009. Effects of bovine colostrum acid protein on bone loss and hemobiochemistry indexes in rats. J. Dairy Sci. Technol. 89:449-461.
Fong, B. Y., C. S. Norris, and K. P. Palmano. 2008. Fractionation of bovine whey proteins and characterisation by proteomic techniques. Int. Dairy J. 18:23-46.

Ginty, F., K. L. Rennie, L. Mills, S. Stear, S. Jones, and A. Prentice. 2005. Positive, site-specific associations between bone mineral status, fitness, and time spent at high-impact activities in 16- to 18-year-old boys. Bone 36:101-110.

Goodman, R. E., S. L. Taylor, J. Yamamura, T. Kobayashi, H. Kawakami, C. L. Kruger, and G. P. Thompson. 2007. Assessment of the potential allergenicity of a milk basic protein fraction. Food Chem. Toxicol. 45:1787-1794.

Grey, A., Q. Zhu, M. Watson, K. Callon, and J. Cornish. 2006. Lactoferrin potently inhibits osteoblast apoptosis, via an LRP1-independent pathway. Mol. Cell. Endocrinol. 251:96-102.

Gu, W., L. R. Kirsten, X. Lin, Y. F. Wang, and Z. J. Yu. 2007. Differences in bone mineral status between urban and rural Chinese men and women. Bone 41:393-399.

Kruger, M. C., R. C. Poulsen, L. Schollum, N. Haggarty, S. Ram, and K. Palmano. 2006. A comparison between acidic and basic protein fractions from whey or milk for reduction of bone loss in the ovariectomised rat. Int. Dairy J. 16:1149-1156.

Lau, E. M. C., H. Lynn, Y. H. Chan, and J. Woo. 2002. Milk supplementation prevents bone loss in postmenopausal Chinese women over 3 years. Bone 31:536-540.

Livney, Y. D. 2010. Milk proteins as vehicles for bioactives. Curr. Opin. Colloid Interface Sci. 15:73-83.

Lu, Y., W. Chai, and X. Lin. 2007. Effect of milk basic protein on rat bone mineral density. Wei Sheng Yan Jiu 36:37-40. (In Chinese).

Naot, D., A. Grey, I. R. Reid, and J. Cornish. 2005. Lactoferrin-A novel bone growth factor. Clin. Med. Res. 3:93-101.

Pouliot, Y., and S. F. Gauthier. 2006. Milk growth factors as health products: Some technological aspects. Int. Dairy J. 16:1415-1420.

Sreedhara, A., R. Flengsrud, V. Prakash, D. Krowarsch, T. Langsrud, P. Kaul, T. G. Devold, and G. E. Vegarud. 2010. A comparison of effects of $\mathrm{pH}$ on the thermal stability and conformation of caprine and bovine lactoferrin. Int. Dairy J. 20:487-494.

Toba, Y., Y. Takada, Y. Matsuoka, Y. Morita, M. Motouri, T. Hirai, T. Suguri, S. Aoe, H. Kawakami, M. Kumegawa, A. Takeuchi, and A. Itabashi. 2001. Milk basic protein promotes bone formation and suppresses bone resorption in healthy adult men. Biosci. Biotechnol. Biochem. 65:1353-1357.

Uenishi, K., H. Ishida, Y. Toba, S. Aoe, A. Itabashi, and Y. Takada. 2007. Milk basic protein increases bone mineral density and improves bone metabolism in healthy young women. Osteoporos. Int. $18: 385-390$.

Zou, Z., X. Lin, X. Xu, R. Xu, L. Ma, Y. Li, and M. Wang. 2009. Evaluation of milk basic protein supplementation on bone density and bone metabolism in Chinese young women. Eur. J. Nutr. 48:301-306. 